Journal of Biotechnology and Bioindustry

Vol.7, December, 2019. 1 4

https://doi.org/10.37503/jbb.2019.7.1

\title{
종양관련 대식세포
}

\author{
김 준 섭
}

충청북도 증평군 대학로 61 한국교통대학교 보건생명대학 식품생명학부 생명공학전공 27909

\section{Tumor-Associated Macrophages: Are Macrophages Enemy or Friendly?}

\author{
Jun-Sub Kim* \\ Department of Biotechnology, Korea National University of Transportation, Jeungpyeong, Chungbuk 27909, Korea
}

\begin{abstract}
The tumor microenvironment is a complex cellular ecosystem that develops with cancer cells during the process of turning them into malignant tumors and provides a support layer for cancer cells. Among the many immune cells that collect at the tumor site, macrophages in particular are the ones that are abundant throughout cancer development. In clinical and mouse studies, macrophages have been shown to play a role in promoting cancer in general. In primary tumors, macrophages stimulate angiogenesis of tumors and increase cancer cell invasion, mobility and vascular invasion. During metastasis, macrophages prepare the site of metastasis and promote the extravascular escape, survival and sustained growth of cancer cells. Macrophages also play an immunosuppressive role, such as preventing natural killer cells or T-cells from attacking cancer cells during cancer progression or recovery after chemotherapy. The success of therapeutic agents targeting these cancer-promoting roles seen in preclinical and early clinical trials suggests that macrophages can be an attractive target for cancer treatment.
\end{abstract}

Key words : macrophage, tumor, cancer, metastasis, cancer therapy

\section{I. 서 론}

우리 몸의 면역체계는 외부로부터 유입된 미생물이나 기 타 물질들인 적들뿐만 아니라, 내 몸 안의 암세포와도 전쟁 을 치른다. 전투 초기에는 주로 대식세포, 호중구, 또는 비만 세포와 같은 선천적 면역세포에 의해 암세포가 제거되고, 시간이 지나면서 $\mathrm{T}$ 세포와 같은 후천면역 세포들이 합세한 전쟁을 치른다. 그럼에도 불구하고, 종양 미세 환경 내에서 가장 풍부한 정상세포인 대식세포는 암세포의 제거보다는 원발성 종양이나 전이부위의 종양 촉진을 하는 것으로 연구 되고 있다(1). 또한, 암의 전이와 연관된 혈관 신생성, 암세 포 침윤, 이동능 및 혈관 내 침윤 등을 촉진시킬 뿐만 아니 라, 전이 부위에서 암세포의 혈관 외 탈출 및 계속적인 성장 에도 도움을 준다. 또한, 암세포의 전이 부위에서 대식세포 를 제거하였을 때 암의 진행과 전이가 억제되었다는 연구결 과들은 암과 면역세포와의 전투가 암이 악성 형질을 획득하

\footnotetext{
*junskim@ut.ac.kr
}

는데 매우 중요하다는 것을 보여준다(2). 결론적으로 대식세 포는 암 치료를 위한 중요한 표적이 될 수 있는 것이다. 본 논문에서는 다양한 대식세포의 기능과 암세포와의 상호작 용 그리고 대식세포의 면역 조절 기능 등에 대해 논하고, 새 로운 방식의 암치료에 있어서 대식세포의 중요성에 대하여 설명하고자 한다.

\section{II. 본 론}

\section{1. 대식세포와 원발성 종양}

종양은 발암유전자 혹은 암 억제 유전자에 발생하는 돌연 변이에 의해 악성으로 진행된다. 비록 대다수의 암 연구들 이 이러한 변화에 초점을 맞추어왔고, 대부분의 치료제들이 암세포에 직접적으로 작용하지만, 종양 미세 환경에 존재하 고 있는 악성이 아닌 세포들이 종양과 함께 발달하며 종양 의 악성 형질에 중요한 도움을 주고 있는 결과들이 밝혀져 왔다(3). 
여러 종류의 자극에 의한 만성염증과 국소 환경의 변화에 의한 다양한 염증반응들이 암을 발생시킨다. 염증반응은 주 로 IL-6, TNF- $\alpha$ 및 IFN- $\gamma$ 와 같은 물질들의 분비를 통해 많은 수의 대식세포를 불러들인다. 이러한 염증은 돌연변이를 유 발하는 미세환경을 조성하여 암을 유발하게 되며, 특히 대 식세포는 성장인자 및 사이토카인들을 생성하여 상피세포 들을 자극하여 암과 연관이 있는 돌연변이를 자연스럽게 유 도한다(4). 다양한 연구 결과들은 대식세포가 염증의 주요 매개 체계로 작용하여 암을 유발한다는 것에 대해 보여주고 있지만, 대식세포가 염증으로 인한 돌연변이 세포(암이 되 지는 않았지만 정상세포는 아닌)들을 제거함으로써 암 억제 작용을 나타내는지에 대한 증거는 명확하지 않다(5).

염증에 의한 암을 유발하는 환경하에서 대식세포들은 면 역적으로 활성화되어 있다. 그러나 일단 암이 발생하게 되 면, 대식세포들은 암을 촉진하도록 재설정된다. 암이 양성 종양에서 전이능이 있는 악성으로 발달하는 과정에서, 종양 미세 환경은 여러 성장인자와 사이토카인에 의해 1형 보조 $\mathrm{T}$ 세포(Th1) 형태의 염증 반응에서 $\mathrm{Th} 2$ 형태의 면역 환경으 로 변화하게 된다. 이 변화는 여러 염증 세포나 암세포가 분 비하는 IL-4, CSF-1(Colony stimulating factor)와 같은 여러 인자들에 의한 대식세포의 변화를 야기한다. 계속 성장하고 싶어하는 종양 조직은 계속적인 돌연변이와 후성적 변화를 필요로 하며, 이로 인한 여러 인자들의 생성이 대식세포들 을 변화하게 만들며, 또한 새로운 단핵구들을 끌어들인 후 그들을 암 촉진 세포로 재분화시켜 지속적인 성장도구로 사 용할 수도 있다(6).

\section{Tumor-associated macrophage(TAM)}

최근 다양한 연구결과들은 각각의 조직에 존재하는 대식 세포들의 기원이 골수(Bone marrow)에서뿐만 아니라, 다양 한 기원이 존재할 수 있음을 제시하고 있다. 실제 조직에 존재하는 대식세포는 대부분이 난황낭(Yolk sac)의 기원 세 포에서 발생하며, 대조적으로 병원균에 대한 반응과 관련 이 있는 대식세포들은 순환하고 있는 골수 단핵구에서 유 래된다(7). 이렇게 대식세포들의 기원이 서로 다름에 따라 $\mathrm{TAM}$ 이 골수세포 유래인지 여부에 의문이 들기 시작하였 다. 서로 다른 대식세포의 기원과 반응에 대한 증거가 생쥐 신경교종(Glioma) 연구를 통해 밝혀졌으며, 종양 미세 환경 에서 난황낭 유래 및 골수 유래 TAM이 모두 존재하며, 항대식세포 치료제에 서로 다르게 반응한다는 것이 제시되었 다. 뿐만 아니라 최근 여러 연구에서 여러 가지 종양에 존 재하는 대부분의 $\mathrm{TAM}$ 이 순환하는 단핵구의 $\mathrm{Ly}_{6 \mathrm{C}} \mathrm{C}^{+}$집단에
서 유래했다는 결과가 제시되었고, 이러한 단핵구들이 골 수에서 직접적으로 유래하는 것이 아니라, 골수외조혈(Extramedullary hematopoiesis)에 의해 비장에서 생성되어, 단 핵구의 저수지 역할을 함으로써 종양 조직으로 공급을 빠 르게 한다는 사실이 밝혀졌다(8). 그러나 최근에 진행된 연 구에 의하면 TAM을 생성하는 데 있어서 비장의 역할은 미 비하며, 골수 유래 단핵구들이 우선적인 근원지라는 것을 밝혔다(9).

CSF-1은 대식세포의 분화 계통을 조절하는데 중요한 인 자이며, 대식세포를 끌어들이는 역할도 한다(10). CSF-1의 농도가 높은 종양은 예후가 좋지 않으며, CSF-1는 종양 부 위 최전선에 있는 조직에서 발현이 발견된다. 이러한 임상 에서의 상황과 유사하게 여러 암 모델에서 CSF-1 유전자의 손실은 $\mathrm{TAM}$ 의 상실로 인해 암 발생의 지연(자궁경부암), 암 진행의 지연(유방암, 췌장암), 암 전이의 지연(유방암)의 연구들이 보고되었다. 또한, 항체, 약물 및 상보적 서열의 $\mathrm{RNA}$ 를 통한 CSF-1R 신호 체계의 저해는 이종이식 및 유전 자 조작 발암 모델에서 암의 악성화에 영향을 준다는 연구 들도 보고되고 있다(11). 그러나 위에서 언급한 치료 전략들 은 순환기 전체적인 효과도 나타내기 때문에 이러한 치료 효과들이 대식세포의 분화 계통에 영향을 미쳐서인지, 종양 내 $\mathrm{TAM}$ 의 생존 및 유입을 직접적으로 저해하여 생긴 효과 인지를 결정하기는 어렵다는 한계를 가지고 있다.

발암유전자 삽입으로 인한 자연발생적 유방암 생쥐모델 (PyMT mouse model)을 통해 진행된 연구에서, 유선 상피세 포에서 과발현된 CSF-1이 대식세포의 유입과 암의 발생을 증가시켰다. CSF-1의 기능을 결손시킨 돌연변이에서는 암 의 진행이 둔화되었고, 전이가 감소되었다. CSF-1이 결손된 PyMT 유방암 모델 생쥐에 유전적으로 VEGFA를 증가시켰 을 때 대식세포의 유입이 증가되었으며, 혈관 신생성이 회 복되었고, 암의 진행과 악성화가 가속화되었다. VEGFA는 대식세포 전구체들을 끌어들이며, IL4의 종양 관련 대식세 포 영향 하에서 $\mathrm{TAM}$ 으로 분화된다(12). 이러한 결과들은 CSF-1과 VEGFA가 각각 독립적인 대식세포 모집자가 될 수 있다는 것을 보여준다. 이런 효과들은 단핵구를 모집하거나, 이미 모집된 혹은 조직에 상주하고 있는 세포들의 증식을 증가시키는 방법을 통해 이루어질 수 있다. 이러한 성장인 자들은 국소부위에서 생성되는 케모카인(Chemokine)과 협 업함으로써 세포들의 모집과 유지를 진행한다(13). 이러한 케모카인의 제거는 단핵구 및 $\mathrm{TAM}$ 의 결손을 유발하며, 결 과적으로 암의 악성화와 성장을 저해하게 된다. 많은 암에 서 특히 초기 단계의 대식세포의 기원은 아직 확실하지 않 으며, 대장암과 같이 여러 미생물에 노출되는 환경과, 상대 
적으로 균의 노출이 적은 조직에서 대식세포의 모집 및 분화 는 차이가 날 것이다. 그럼에도 불구하고 $\mathrm{TAM}$ 의 기원과 모 집, 유지 및 분화 등에 대한 내용은 흥미로운 부분이며, 작용 기전을 이해하는 것은 암을 촉진하는 대식세포 집단의 모집 을 표적하는 치료요법의 가능성을 열어줄 것으로 보인다.

\section{3. 대식세포와 암세포의 전이}

종양이 원발성 암 발생 부위에서 탈출하게 되면, 그들은 림프계 및 순환계를 통하여 다른 부위들로 이동하여 전이하 게 된다. 이러한 부위들은 암의 종류에 따라 다르며, 예를 들어 유방암은 주로 뼈, 폐 및 뇌로 전이된다. 선진국에서 고형암으로 인한 사망의 약 $95 \%$ 가 전이에 의한 것임을 볼 때 이 과정을 이해하는 것은 중요하다(14). 단핵구와 대식세 포는 전이를 촉진하는 역할에 있어서 전이 부위를 준비시키 는 것과 암세포의 혈관 외 탈출, 생존 및 계속적인 성장 모 두에 있어서 중요하다. 심지어 암세포가 도착하기 전에도, 전이의 빈도나 전이된 암조직의 성장은 전-전이틈새(Premetastatic niche)라고 불리는 부위의 형성을 통해 순환하는 암세포의 유도를 증가시킴으로써 원발성 종양에 의해 영향 을 받는다. 이 틈새는 Lysyl Oxidase(LOX)와 S110A에 의해 모집되는 $\mathrm{Cd} 11 \mathrm{~b}+\mathrm{VEGFR}-$ 골수성 세포로 이루어져 있으며, 이것을 억제하였을 때 이 틈새의 형성이 저해된다(15).

폐 전이에 대한 연구들에서 암세포들이 표적 부위에 도착 하게 되면, 혈소판들과 함께 미세응고물을 형성하여 표적 조직의 혈관들을 끌어당긴다. 이를 통해 종양 세포는 CCL2 를 분비하여 CCL2 수용체인 CCR2를 발현하는 $\mathrm{Ly} 6 \mathrm{C}$ 단핵 구들을 모집하며, 또한 이 응고물은 혈관 내피세의 VECM1 을 증가시켜 단핵구들의 응집을 증가시킨다. 이렇게 모인 단핵구들은 $\mathrm{VEGF}$ 의 발현을 통해 혈관 투과성을 증가시켜 암세포의 혈관 외 탈출을 증가시킨다. 이와 같은 맥락으로, $\mathrm{CCR} 2$ 를 저해하게 되면 암세포의 혈관 외 탈출을 막으며, 전이를 감소시킨다. 이러한 단핵구들은 $\mathrm{CCR} 2^{+}, \mathrm{VEGFR} 1^{+}$, $\mathrm{Ly}_{6 \mathrm{c}}{ }^{-}, \mathrm{F} 4 / 80^{+}$전이 관련 대식세포 (Metastasis associated macrophage, MAMs)로 분화한다(16). 유전적 및 화학적 방 법으로 이 MAM 집단을 제거하게 되면 암세포의 전이 및 성장뿐만 아니라 심지어 이미 전이가 된 이후에도 억제 효 능을 나타낸다(17). 골수세포는 또한 TGF- $\beta$ 신호의 저해를 통해 MET(Mesenchymal-to-Epithelial Transition)와 암세포 성 장을 촉진한다. 많은 암세포들, 특히 유방암과 전립선암은 골전이가 일어난다. 이 과정에서 단핵 식세포 계열인 파골 세포가 중요한 역할을 한다. 이 세포는 전이 세포에 의해 활 성화되어 뼈를 분해하고, 성장인자를 분배하여 악순환을 낳
는다(18).

\section{4. 암 치료 타겟으로서의 TAM}

면역반응에 있어서 대식세포는 IFN- $\gamma$, TNF- $\alpha$ 및 TLR4 에 반응하여 활성화되는 M1 대식세포와 IL-4 또는 IL-13에 의 해 활성화되는 M2 대식세포로 분류된다(7). TAM 또한 이 러한 방법을 따라서 종양 사멸(M1), 종양 촉진(M2)으로 나 눌 수 있지만, 서로 다른 암의 종류에서 다른 생물학적 반응 을 나타내는 TAM의 다양한 형태에 대한 보고들은 이러한 정의에 한계가 있음을 제시하고 있다(19). 또한, M1과 M2 대식세포를 특이적으로 제거하여 역할을 밝힌 확실한 연구 결과가 없다는 점에서 그들이 암 촉진에 미치는 영향은 아 직 밝혀지지 않았다고 할 수 있다. 하지만 TIE2 ${ }^{+}$나 MAM과 같은 특이적인 하위 그룹을 제거한 실험에서는 대식세포가 혈관신생성이나 전이성 파종과 같은 특이적인 기능에 미치 는 영향에 대해서 제시할 수 있었다(5).

현재까지의 대식세포를 표적으로 한 치료 전략은 대식세 포의 분비기능과 면역 억제를 저해하거나, 그들의 항암 활 성을 촉진하는 것에 국한되어있다. 최근 몇몇 연구들은 이 러한 전략이 치료에 효과가 있다는 것을 제시하고 있다. 현 재까지 치료법 중 주요한 전략은 CSF-1 신호체계를 저해하 여 암의 진행과 전이를 막은 연구와, CSF-1 수용체 중화 항 체 및 저분자 저해제를 통해 CSF1 신호를 저해한 연구에 기 반하고 있다. 놀랍게도, CSF-1R를 저해하였을 때 생쥐 모델 에서 종양의 크기가 비약적으로 감소하였다. CSF-1R의 저 해는 TAM을 사멸시키지 않고, GM-CSF에 의해 조절되는 항암 활성을 가지는 상태로 변화시켰다. 이와 유사한 결과 가 자궁경부암과 유방암 모델에서도 발견되었다. CSF-1R를 표적하는 저분자 저해제는 $\mathrm{TAM}$ 의 일부 집단을 제거하였고, 화학적 항암요법에 대한 반응성을 비약적으로 증가시켰다. 이 효과는 종양의 회복 시기에 대식세포의 면역억제를 줄여 준 것에 일부 기인한 것으로 보인다. TIE2 $2^{+} \mathrm{TAM}$ 은 혈관치 료제의 효과 또한 저해하기 때문에 이러한 개선 효과는 화 학적 치료요법에만 제한되지 않고 혈관치료제에 대한 반응 성 또한 비약적으로 증가시켰다. 대식세포는 단일 항체 치 료제의 효과를 증가시키기도 한다. 또한, 항암제 Trabectedin 은 단핵구와 대식세포를 직접적으로 죽이며, 생쥐 모델에서 암에 대한 억제 효과를 보였다. 유사하게도, amphotericin B 는 대식세포를 통한 신경교종 종양 개시세포(tumor initiating cell) 억제를 증가시켰다(20). 이러한 사례들을 종합해볼 때 대식세포를 재분화시키거나 제거하는 것이 암 치료를 위한 중요한 복합요법이 될 수 있음을 뒷받침한다. 


\section{III. 결 론}

최근 다양한 전임상 연구 결과들은 $\mathrm{TAM}$ 의 제거나 재분 화의 방법으로 암 치료에 도움을 줄 수 있는 증거를 제시하 고 있다. 특히, 대식세포는 정상세포로서 암세포처럼 증가된 돌연변이 발생을 통한 약물 저항성을 보이지 않기 때문에 $\mathrm{TAM}$ 을 통한 접근은 매력적인 방법이 될 수 있다. CSF-1R 신호체계 표적을 통해 종양 촉진 대식세포를 제거하는 임상 시험이 진행되고 있기는 하지만, 대식세포 전체에 대한 치 료적 접근은 전신 독성을 야기할 가능성 있기에 신중한 접 근이 필요해 보인다. 그리고 외부로부터 모집된 대식세포와 상주하고 있던 대식세포의 기원이 다르다는 것을 발견한 것 은 TAM을 특이적으로 표적하는 정교한 치료 방법이 가능 하다는 것을 제시해준다. 또, 다른 흥미로운 치료적 접근은 대식세포의 면역 억제 효능 제거를 통해 화학 요법이나 면 역 요법에 대한 반응성을 증가시키는 것이다. 향후, 암과의 전쟁에서 승리하기 위해서는 대식세포에 대한 더욱 깊고 체 계적인 연구가 필요해 보인다.

\section{참고문헌}

1. Gajewski TF, Schreiber H, Fu YX. (2013) Innate and adaptive immune cells in the tumor microenvironment. Nature Immunology. 14, 1014 22.

2. Biswas SK, Allavena P, Mantovani A. (2013) Tumorassociated macrophages: Functional diversity, clinical significance, and open questions. Seminars in Immunopathology. $35,585 \sim 600$.

3. Joyce JA, Pollard JW. (2009) Microenvironmental regulation of metastasis. Nature reviews. Cancer. 9, 239 52.

4. Grivennikov SI, Greten FR, Karin M. (2010) Immunity, inflammation, and cancer. Cell. 140, 883 99.

5. Qian BZ, Pollard JW. (2010) Macrophage diversity enhances tumor progression and metastasis. Cell. 141, 39 51.

6. Coussens LM, Zitvogel L, Palucka AK. (2013) Neutralizing tumor-promoting chronic inflammation: A magic bullet? Science. 339, 286 91.

7. Wynn TA, Chawla A, Pollard JW. (2013) Macrophage biology in development, homeostasis and disease. Nature. 496, 445 55.

8. Franklin RA, Liao W, Sarkar A, et al. (2014) The cellular and molecular origin of tumor-associated macrophages.
Science. $344,921 \sim 5$.

9. Cortez-Retamozo V, Etzrodt M, Newton A, et al. (2012) Origins of tumor-associated macrophages and neutrophils. Proc Natl Acad Sci USA. 109, 2491 6.

10. Chitu V, Stanley ER. (2006) Colony-stimulating factor-1 in immunity and inflammation. Curr Opin Immunol. 18, 39 48.

11. Laoui D, Movahedi K, Van Overmeire E, et al. (2011) Tumor-associated macrophages in breast cancer: Distinct subsets, distinct functions. Int J Dev Biol 55, 861 7.

12. Lin EY, Pollard JW. (2007) Tumor-associated macrophages press the angiogenic switch in breast cancer. Cancer Res. 67, 5064 6.

13. Su S, Liu Q, Chen J, et al. (2014) A positive feedback loop between mesenchymal-like cancer cells and macrophages is essential to breast cancer metastasis. Cancer Cell. 25, 605 20.

14. Oyce JA, Pollard JW. (2009) Microenvironmental regulation of metastasis. Nature reviews. Cancer. 9, 239 52.

15. Psaila B, Lyden D. (2009) The metastatic niche: Adapting the foreign soil. Nature reviews. Cancer. 9, 285 93.

16. Qian BZ, Li J, Zhang H, et al. (2011) CCL2 recruits inflammatory monocytes to facilitate breast-tumor metastasis. Nature. 475, 222 5.

17. Qian B, Deng Y, Im JH, et al. (2009) A distinct macrophage population mediates metastatic breast cancer cell extravasation, establishment and growth. PloS One. 4, e6562.

18. Gao D, Joshi N, Choi H, et al. (2012) Myeloid progenitor cells in the premetastatic lung promote metastases by inducing mesenchymal to epithelial transition. Cancer Res. 72, 1384 94.

19. Sica A, Larghi P, Mancino A, et al. (2008) Macrophage polarization in tumor progression. Semin Cancer Biol 18, 349 55.

20. De Palma M, Lewis CE. (2013) Macrophage regulation of tumor responses to anticancer therapies. Cancer Cell. 23, 277-86.

Received Dec. 3, 2019, Revised Dec. 27, 2019, Accepted Dec. 27, 2019 